\title{
Sabine Stach
}

German Historical Institute, Warsaw

\section{AN ORDINARY MAN, A NATIONAL HERO, A POLISH PALACH? SOME THOUGHTS ON THE MEMORIALIZATION OF RYSZARD SIWIEC IN THE CZECH-POLISH CONTEXT ${ }^{*}$}

\begin{abstract}
On 8 September 1968, Ryszard Siwiec set fire to himself during a harvest festival in the 10th Anniversary Stadium in Warsaw. Through his self-immolation, he sought to protest against Communist rule in general and the Warsaw Pact invasion of Czechoslovakia in particular. However, his death did not gain wider attention. Further protests 'by fire' took place in the subsequent months and years in East Central Europe. Among them was the self-immolation by the Czech student Jan Palach in Prague. In contrast to Siwiec, this young man was immediately recognised as a martyr in Czechoslovakia as well as on the other side of the Iron Curtain. It was only after 1989 that Ryszard Siwiec's story became increasingly well-known. Today, his act still remains in the shadow of Palach's, however. This article deals with the marginal position of Siwiec in the Polish national pantheon. By reflecting on the various constraints on creating martyrs in state and post-socialism, it focuses on one particular aspect of Polish and Czech - or rather Polish-Czech memory politics. As for the 'Polish Palach' Ryszard Siwiec, the paper demonstrates that Czechs have played a crucial role in popularizing him.
\end{abstract}

Keywords: Ryszard Siwiec, Jan Palach, memory politics, self-immolation, political martyrs

In 2008, the regional branch of the Polish Instytut Pamięci Narodowej (Institute of National Remembrance, IPN) in Rzeszów prepared an exhibition entitled Krzyk szarego człowieka. Ryszard Siwiec (19091968) (An Ordinary Man's Cry. Ryszard Siwiec [1909-68]). On the occasion of the 40th anniversary of his death, the authors sought

* The findings presented here are based on my PhD research. See Sabine Stach, Vermächtnispolitik. Jan Palach and Oskar Brüsewitz als politische Märtyrer (Göttingen, 2016). 
to raise awareness about a man who on 8 September 1968 set fire to himself in the Stadion Dziesieciolecia (10th Anniversary Stadium) in Warsaw. Through his self-immolation in the crowded stadium, Siwiec sought to protest against Soviet-led Communist rule in general and the Warsaw Pact invasion of Czechoslovakia in particular. ${ }^{1}$ Although he tried to distribute leaflets explaining his convictions before he was taken away to a hospital, it was only from the 1990s onwards that his act became widely known. The self-immolation had been carefully - and successfully - suppressed from public discourse by the Communist authorities. In 1991, the filmmaker Maciej Drygas took up the subject and more people began to learn about Siwiec and his act of political resistance. For his documentary, Ustyszcie mój krzyk (Hear My Cry), Drygas used archival material which showed the very moment of Siwiec setting himself on fire and featured interviews with eyewitnesses. ${ }^{2}$

Yet in the pantheon of Polish heroes, Ryszard Siwiec is by no means the first to come to mind. Rather, he remains in the shadow of various other protagonists. A far more prominent martyr of the Communist past in Poland is the Catholic priest Jerzy Popiełuszko (now Blessed of the Catholic Church), who was murdered by state security officers in 1984. Unlike Siwiec, the organizer of huge patriotic masses was famous already prior to his death. But, even in the history of self-immolation as a form of political protest in East Central Europe, Ryszard Siwiec did not attract as much attention as other cases. He is far less recognizable than the Czech students Jan Palach and Jan Zajíc, who committed protest suicides in 1969 in Prague, or Romas Kalanta, who set fire to himself in 1972 in the Lithuanian SSR.

${ }^{1}$ For information regarding Ryszard Siwiec, his self-immolation, and its direct consequences, see Petr Blažek, Živá pochodeñ na Stadionu Desetiletí: Protest Ryszarda Siwce proti okupaci Československa $v$ roce 1968 (Praha, 2008). This publication was also translated into Polish: idem, Ryszard Siwiec 1909-1968 (Warszawa, 2010). See also Łukasz Kamiński, 'Przeciw totalnej tyranii zła. Ryszard Siwiec (1909-1968)', Pamięć.pl, 9 (2013), 48-50, <http://pamiec.pl/pa/tylko-u-nas/12823,PRZECIWTOTALNEJ-TYRANII-ZLA-RYSZARD-SIWIEC-19091968-artykul-prezesa-IPNLukasza.html> [Accessed: Oct. 15, 2015].

${ }^{2}$ Ustyszcie mój krzyk, directed by Maciej Drygas, Studio Filmowe Logos, Zespół Filmowy Zodiak, 1991, 46 min. The material collected by Drygas is accessible in the KARTA archive Warsaw (AO III/301) and was partly published in the following publications: 'Płomień Ryszarda Siwca', Karta, 44 (2005), 78-97; Agnieszka Dębska and Bartosz Kaliski (eds.), Całopalny. Protest Ryszarda Siwca (Warszawa, 2013). 
The above-mentioned exhibition, which was first shown in Siwiec's home town of Przemyśl, demonstrates that the Rzeszów branch of IPN considered the then state of knowledge about Ryszard Siwiec to be insufficient. The fact that his identity is partly derivative as a 'Polish Palach', instead of being an independent symbol of resistance, is symptomatic of the lack of public memory that marginalizes Siwiec's merits in Poland and beyond. IPN's initiative can therefore be understood as an attempt to correct this 'shortcoming' by means of direct historical-political engagement. Thus, the exhibition became the basis for a multimedia project consisting of a (free) e-book and a website under the same title. In their mission statement, the authors point out that they aim to reach a wider audience in order to ensure that Siwiec "will not only be remembered by the Poles, but also Czechs and other nations." 3

This paper departs from the discernible desire of some Czech and Polish actors to 'improve' the remembrance of Ryszard Siwiec's 'heroism', ${ }^{4}$ which is allegedly overshadowed by the greater fame of Jan Palach. By taking up the question of history and politics, I will focus on the politics of memory ${ }^{5}$ of post-socialist political 'martyrs'. The symbolic capital embodied by both Palach and Siwiec as fighters for democracy and freedom is a highly ambivalent one. The commemoration of their self-immolation touches upon questions of moral responsibility and the embarrassing moments of national history. Furthermore, this remembrance is part of symbolic dynamics on a transnational level. Therefore, I will argue that the relative anonymity of Ryszard Siwiec does not only stem from the fact that the Polish Communist rulers were very successful at suppressing the knowledge of his suicide protest. Rather, it has to be explained by a more complex

${ }^{3}$ Jakub Izdebski and Marcin Krzanicki, About the project, <http://www.ryszardsiwiec.com/oprojekcie_en.html> [Accessed: Oct. 11, 2015].

${ }^{4}$ Ibidem. The web project was launched in English, Polish, and Czech. While the Czech and Polish versions use the term "heroism" or "hero" (Polish "bohaterstwo/bohater", Czech "hrdina/hrdinství"), the English translation interestingly avoids a similar normative characterization. The term "heroism" is also used by Łukasz Kamiński. See Kamiński, 'Przeciw totalnej tyranii zła', 50.

${ }^{5}$ Aware of the plurality of definitions, I use the term 'politics of memory' here as a translation of the German term Geschichtspolitik as it was conceptualized for example in Bernd Faulenbach, 'Zeitwende 1989/1990 - Paradigmenwechsel in der Geschichtspolitik?', in Beatrix Bouvier et al. (eds.), Geschichtspolitik und demokratische Kultur. Bilanz und Perspektiven (Bonn, 2008), 85-95. 
set of restrictions on the discourse of and multidimensional obstacles to appropriation.

In order to reflect on these political-symbolical constraints on creating martyrs, I will compare the 'successful' memorialization of Palach with the case of Siwiec. By taking into account historiography and literature alongside newspaper articles, films and commemorative activities, the different processes of medialization and memorialization can be studied and their entanglements and overlappings carved out. The comparative view on both cases can contribute to a better understanding of the varying discursive limits. In the first part of the paper, I will therefore provide a rough summary of the different political-symbolical contexts which shaped the commemoration of Palach and Siwiec. In the second part, I present the ambivalence of appropriation from two different perspectives. First, moral problems tied to the act of self-immolation and 'oppositional self-sacrifice' in general will be discussed. Second, I will situate the remembrance of Siwiec within the Czech-Polish context by taking into account the difficult heritage of the 'Prague Spring' and the Warsaw Pact invasion. A final brief note on the symbolic dynamics of discourse surrounding martyrs will serve to sum up the iconographic dominance of Jan Palach over his Polish forerunner.

\section{I \\ RYSZARD SIWIEC: SILENCE AND COMMEMORATION, 1968-2012}

Ryszard Siwiec was a family man and father of five children, born in the small town of Dębica in southeastern Poland. ${ }^{6}$ In the Second World War, he was part of the underground movement and fought in the ranks of the Armia Krajowa (Home Army) against the German occupiers. In March 1968, he became engaged in oppositional activities and started printing and distributing leaflets signed with the pseudonym 'Jan Polak'. On 8 September 1968, he participated in one of the great propaganda events established in Władysław Gomułka's

${ }^{6}$ For the biography, see e.g. Adam Macedoński, Ryszard Adam Siwiec, in Polski Stownik Biograficzny, xxxvii, 4 (155) (Warszawa and Kraków, 1997), 615-16; Małgorzata Stracz, Ryszard Siwiec, in Opozycja w PRL. Stownik biograficzny 19561989, ii (Warszawa, 2002), 282-3. 
Poland - a harvest festival in the 10th Anniversary Stadium. During a dance ceremony, Siwiec stood up, set fire to himself, and began to shout and hand out leaflets. However, the main cameras were turned away from his protest. The dance went on as firemen and policemen began removing Siwiec from the scene as quickly as possible. Thus, the majority of the more than 100,000 visitors to the stadium were not even aware of his act of protest. The Polish newspapers did not report it. The first international magazine to publish any information about it was the French Le Nouvel Observateur in January 1969 - four months after Siwiec's death and a few days following Jan Palach's self-immolation in Czechoslovakia. ${ }^{7}$

Why did Siwiec set himself on fire? According to what we know of the latest research, he had planned his protest a couple of months in advance. As early as March 1968, he had written his last will and criticized the state of socialism in Poland in his writings. The military intervention in Czechoslovakia by troops of the Warsaw Pact in August 1968 was the main event that informed his final decision to burn himself alive. In a testimony he had recorded in advance and intended to be published after his death, he criticized not only the intervention, but the Polish participation in it in particular and appealed to the people: "Hear my cry! An ordinary man's cry, a son of the nation, who loves his and others' freedom more than anything, more than his own life! Come to your senses! It's not too late!"8

Apart from rumors, ${ }^{9}$ there was no public knowledge about Ryszard Siwiec. As opposed to Jan Palach, who became known all over the world as a symbol of resistance just a few months later, Siwiec's protest was not picked up by media outlets before 1989 . Tellingly enough, one Polish writer who did reflect on public suicides as a mode of resistance in state socialist Poland did not refer to Siwiec, but to other examples. In his 1979 novel Mała apokalipsa (A Minor Apocalypse), ${ }^{10}$ Tadeusz Konwicki writes of the last day of a young man in the People's Republic of Poland who decides to set himself

${ }^{7}$ Besides Blažek, Ryszard Siwiec, see also Łukasz Kamiński, 'První živá pochodeň ve východním bloku', in Petr Blažek et al. (eds.), Palach '69 (Praha, 2009), 115-27; Dębska and Kaliski (eds.), Całopalny, 34-6.

${ }^{8}$ Fragment of the recording from 7 September 1968, in Dębska and Kaliski (eds.), Catopalny, 32.

${ }^{9}$ Ibidem, 34.

${ }^{10}$ Tadeusz Konwicki, Mała apokalipsa (Warszawa and Londyn, 1979). 
on fire by the end of the day. The novel, published by the underground press (in the so-called drugi obieg) locates the plot in the city center of Warsaw, where the act of self-immolation takes place symbolically in front of the Palace of Culture and Sciences. Nevertheless, the Polish author does not allude to Ryszard Siwiec, but rather to other Buddhist, Lithuanian, and Czech cases. ${ }^{11}$

It appears that there were only very few references made to Siwiec in Poland before $1989 .{ }^{12}$ The only publication dedicated to Siwiec's protest was an underground leaflet from 1981 written by Wit Siwiec, one of Ryszard's sons. In his small brochure, 8 września 1968. Żywa pochodnia na stadionie X-lecia (The Eighth of September 1968: A Living Torch in the 10th Anniversary Stadium), he calls on people not to forget his father's sacrifice and describes him as a national hero, making several historical mistakes and exaggerations along the way. ${ }^{13}$ It was only after 1989 that additional information was made available. At the beginning of that year, the first initiatives emerged to commemorate Siwiec. Triggered by the Palach demonstrations in Prague in January $1989,{ }^{14}$ which became well-known in Poland as well, several press articles in Tygodnik Solidarność demanded that tribute also be paid to the 'Polish Palach'. ${ }^{15}$ In the summer of 1989 - already after the Civic Committee Solidarność had entered the Polish parliament in June - several groups were founded to promote his remembrance. One of these was set up by Adam Macedoński and Zygmunt Karcz and explicitly referred to both Siwiec and Palach as Wspólnota im. R. Siwca i J. Palacha $w$ Polsce (The R. Siwiec and J. Palach Community in Poland). Furthermore, the anti-Communist Federacja Młodzieży Walczacej (The Federation of Fighting Youth) called for a demon-

11 Tadeusz Konwicki, Mała apokalipsa (Warszawa, 2010), 180.

${ }^{12}$ At least the KARTA-Archive in Warsaw, which holds a collection with material about Ryszard Siwiec, does not give evidence of further publications.

${ }^{13}$ Wit Siwiec, 8 września 1968. Żywa pochodnia na stadionie X-lecia ([Wrocław], 1981). In 1989, the Federation of Fighting Youth (Federacja Młodzieży Walczacej) published the booklet again. In his text, Wit Siwiec claims, for example, that his father set himself on fire while Gomułka was speaking and then managed to run into the middle of the stadium.

${ }^{14}$ See below.

${ }^{15}$ Zygmunt Karcz, 'Polski Palach', Tygodnik Solidarność, 8 (1989); Wspólnota im. R. Siwca i J. Palacha w Polsce, 'Posłanie', Tygodnik Solidarność, 11 (1989). Siwiec is also introduced as a 'Polish Palach' in Malcolm Peters, 'Nieznany Polski Palach', The Polish Express, 147 (12 Oct. 1990). 
stration in Przemyśl. ${ }^{16}$ In 1990, the editors of Tygodnik Solidarność initiated a memorial plaque at the Warsaw Stadium where the selfimmolation had taken place.

Apart from small annual commemorative activities organized by the newspaper's editors in the following years and some occasional newspaper articles calling on the Polish people to finally pay tribute to the heroic act of protest, ${ }^{17}$ there was hardly any public activity concerning Siwiec over the following 20 years. Only since 2009 have commemorative activities increased: On the occasion of the centennial of the birthday of Ryszard Siwiec, a solemn ceremony was organized in his home town Dębica. The event had several parts, including the unveiling of a commemorative plaque on the wall of his former school, the exhibition by IPN Rzeszów, a mass, and a conference dedicated to the self-immolation. The whole anniversary was explicitly organized as an act of Polish-Czech-Slovak cooperation, with political representatives from all three countries. ${ }^{18}$

The Czech participation has to be situated within the wider context of the 40th anniversary of Palach's death (see below). The various commemoration activities which had taken place in Prague in January that year had already included Siwiec and other acts of self-immolation. ${ }^{19}$ Besides, a street in Prague was named after him in 2009, and in 2010 a monument was placed in that very street in front of the Czech equivalent of the IPN, Ústav pro studium totalitních režimů (Institute for the Study of Totalitarian Regimes) ${ }^{20}$ The black obelisk was designed by Marek Moderau, a Polish sculptor. It was only in 2011, though, that a street in Warsaw was named after Siwiec, situated next to the new National Stadium, close to the actual site of his deed. A copy of Moderau's monument was erected here

${ }^{16}$ Warsaw, KARTA-Archive, Regiony FMW, Przemyśl, F/02.12.01, 'Ulotka FMW Przemyśl i PPS-RD wzywająca do manifestacji w związku z 21. rocznicą samospalenia Ryszarda Siwca'.

${ }^{17}$ Jerzy Szperkowicz, 'Dzień Opamiętania', Gazeta Wyborcza (12 June 1993); Jerzy Pilch, 'Chwila opamiętania', Gazeta Wyborcza (24 Sept. 1993); 'Ryszard Siwiec', Tygodnik Solidarność, 38 (1999); 'Pamięci Ryszarda Siwca', Tygodnik Solidarność (20 Sept. 2002).

${ }^{18}$ A documentation of the anniversary event has been published in 2015: Ryszard Siwiec. Pro memoria (Tarnów and Dębica, 2015).

${ }^{19}$ See the multi-media website documentation created from the anniversary project: <http://www.janpalach.cz/> [Accessed: Oct. 15, 2015].

20 'Pomnik upamiętniający samospalenie Siwca', Rzeczpospolita (20 Aug. 2010). 
in 2012. ${ }^{21}$ Moreover, Siwiec was honored with highest state awards. Again, the Polish initiative can be interpreted as a reaction to an earlier Czech one: Two years before Siwiec was posthumously awarded the Polish decoration Polonia Restituta in 2003, he had been honored with the Czech Tomáš-Garrigue-Masaryk-Medal by Václav Havel in 2001.

II

\section{THE DISCURSIVE FRAMEWORK: JAN PALACH}

On 16 January 1969, four months after Ryszard Siwiec's tragic selfimmolation in Warsaw, the 20-year-old Jan Palach set fire to himself in Prague. ${ }^{22}$ Through this act, he intended to protest against the violent termination of the socialist reform project under Alexander Dubček. Like most Czech people, the student at Charles University in Prague enthusiastically supported the liberalization that had taken place since 1968 and joined the nationwide protests against the Warsaw Pact invasion on 21 August 1968. In January, this resistance had more or less disappeared. Desperate on account of the atmosphere of hopelessness and resignation, Palach sought to make a stand against the official policy and remobilize the protests by burning himself alive on Wenceslas Square in the center of Prague. His act shocked both the Western and Eastern worlds, giving the students' and workers' resistance in the ČSSR a new impetus, albeit a shortlived one. After three days, Jan Palach died. The huge mourning ceremony, organized by the students of Charles University, presented him as a national martyr, who had made the "highest sacrifice on the altar of the nation". ${ }^{23} \mathrm{He}$ was immediately integrated into Czech national imagery through frequent references to the reformer Jan Hus, who was burnt at the stake in $1415 .{ }^{24}$ In addition to this, his name

${ }^{21}$ Dębska and Kaliski (eds.), Całopalny, 47.

${ }^{22}$ For Jan Palach, his motivations, his deed, and its consequences and cultural reception, see the various articles in the compendium by young Prague historians: Blažek et al. (eds.), Palach '69.

${ }^{23}$ Mourning speech of the Charles University rector Oldřich Starý, quoted from: Josef Culek (ed.), Palach. 11.8.1948-19.1.1969 (Praha, 1990), 34 ff., here 35.

${ }^{24}$ Robert B. Pynsent, Questions of Identity - Czech and Slovak Ideas of Nationality and Personality (New York, 1994), 209; Ladislav Holy, The Little Czech and the Great Czech Nation. National identity and the post-communist social transformation (Cambridge MA, 1996), 44-6. 
became well-known around the world, both as a symbol of resistance and as a personification of non-violent protest - a form of protest attributed to the Czechs and Slovaks as particularly characteristic. ${ }^{25}$

This motif returned in January 1989 when five independent groups called for a public commemoration of the 20th anniversary of Palach's death in Prague. At the time, Palach was used quite strategically in order to reclaim the public sphere and challenge the hegemony of Communist discourse. The main initiators of the commemoration were arrested before the actual meeting, and police dispersed the gathering on Wenceslas Square. The breakup of the protest was one reason why people continued to demonstrate over the following days. Today, the days of demonstration are commemorated and popularly known as 'Palach week' ${ }^{26}$ and said to be the actual beginning of the so-called 'Velvet revolution'.

Connecting these major reference points of the Palach reception in 1969 and 1989, today's teleological master narrative culminates in the claim that Palach's legacy was fulfilled with the revolution of 1989. Since then, his protest has been popularized as both a universal act of resistance and a patriotically motivated sacrifice for freedom and democracy. This interpretation can be found in the national as well as the international political discourse on (the end of) the Cold War. The transnationally valid symbolic capital of Palach as an icon of resistance even helped symbolically integrate his country (since 1993, the Czech Republic) into the Western political system. In his speech on the eve of the Madrid NATO summit in 1997 - the meeting that initiated the Czech Republic's negotiations for membership - Romano Prodi, for instance, referred to Palach as a guarantor of Western values:

For four decades, the Czech people have stood out as a magnificent example of courage, dignity, and devotion to the same goals as the Alliance. Twentynine years ago, in the fateful summer of 1968, the Czech people rose up against oppression and paid a heavy toll for their love of freedom. Jan Palach

${ }^{25}$ For comprehensive analyses about the Palach cult from cultural historical perspectives, see Christiane Brenner, 'Tod für einen Sozialismus mit "menschlichem Gesicht". Jan Palach', in Rainer Gries et al. (eds.), Sozialistische Helden. Eine Kulturgeschichte von Propagandafiguren in Osteuropa und der DDR (Berlin, 2002), 256-66; Charles Sabatos, 'Hořící tělo jako ikona odporu. Jan Palach v české a světové literatuře', Kuděj, vi, 2 (2004), 59-77.

${ }^{26}$ Vilém Prečan et al. (eds.), Horký leden 1989 v Československu (Praha, 1990). 
became a symbol of the human spirit fighting against oppression. A turning point was reached: the mask of oppression fell. Nothing, ever, was the same again in Europe. ${ }^{27}$

III

SELF-SACRIFICE AS A PROBLEM: CONSIDERATIONS FROM A MORAL AND A FUNCTIONAL POINT OF VIEW

What may appear like a clear story with a nice 'happy ending' was hardly the case, however. Taking up what was regarded as Palach's 'legacy', his 'heirs' had to overcome a whole set of moral obstacles. First of all, Palach had left a letter signed by „torch no. 1”. According to his own writings, he was part of an entire resistance group whose members would commit further protest suicides until their demands (e.g., the re-abolition of censorship) were met. ${ }^{28}$ This risk of more young people killing themselves made the tribute to Palach's heroic 'self-sacrifice' highly problematic. In fact, more self-immolations took place in the following months, among them Jan Zajíc, a high-school student, who explicitly referred to Palach in his last letter. Although the existence of a group behind Palach has never been proven, the danger of other suicides restricted positive acknowledgments of the form of protest in public.

Second, understanding self-immolation ${ }^{29}$ in terms of religious self-sacrifice was, of course, highly problematic from a moral point of view - not only because Christianity, unlike Buddhism, clearly rejects suicide. More fundamental is the ontology of martyrdom. The question of whether a martyr can be a martyr at all if he willingly seeks to be one is a theological problem that has been discussed since the beginning of Christianity. In the case of Palach, the question was resolved in a dialectical way in 1969: the Czech Cardinal Josef Beran, like other Catholic priests, openly honored the sacrifice, while at the

${ }^{27}$ Romano Prodi, Toward an Undivided Safer Europe. 14th International Workshop on Global Security - Prague, 21-25 June 1997, <http://www.csdr.org/97Book/ prodi-C.htm> [Accessed: Oct. 11, 2015].

${ }^{28}$ Blažek et al. (eds.), Palach '69, D 2 - D 6.

${ }^{29}$ In a literal translation the English term, "self-immolation" means "selfsacrifice". However, the term is used today to describe the phenomenon of public suicides by setting fire to oneself. See Michael Biggs, 'Dying without Killing: Self-Immolations, 1963-2003', in Diego Gambetta (ed.), Making Sense of Suicide Missions (Oxford, 2005), 173-258, here 174. 
same time clearly condemning the form the student had chosen. In his speech on Radio Vatican, he said, "I bow to his heroic courage, although I cannot admire his desperate deed." 30

What becomes obvious from those first ambivalent reactions to the act of protest is the difficulty of facing the sheer shock of Palach's suicide and equipping it with a positive meaning. The problems emerged not only from a religious, but also a cultural point of view. At the time, the only known self-immolations were those of Buddhist monks in Vietnam. Integrating this 'non-European' mode of resistance into Czech national imagery was not possible directly, as Ladislav Holý pointed out: It had to be mediated through powerful domestic symbols, via the image of 'fire' that connected Palach's deed with the martyrdom of Jan Hus at the stake in Constance. ${ }^{31}$

Returning to the case of Ryszard Siwiec, we do not find a similar mechanism that would serve to facilitate his entry into the world of Polish symbols. The existing national narratives of martyrdom, which are mainly based on the messianic idea of Poland as the 'Christ of nations', left no space for a public suicide. The fact that Siwiec himself prepared a white-and-red flag with the inscription "Za Naszą i Waszą Wolność. Honor i Ojczyzna" (For Our Freedom and Yours. Honor and Fatherland) and appealed to people not to lose their faith in God ${ }^{32}$ could not close the gap. Even if his patriotic language had been heard by a wider audience, it remains highly questionable whether it could have contributed to a heroic image within the national discourse.

Another problem of appropriation becomes evident when taking a closer look at the claim that Palach was something akin to an 'oppositional hero' or at least a role model for dissidents. Of course, his symbolic capital as an icon of resistance was used strategically at the end of the 1980s. By analyzing the Czech dissident discourse in the 1970s and the beginning of the 1980s, it becomes clear that there were not many positive references to the violent suicide. On the contrary, some dissidents openly criticized the mythologization of Palach, arguing that in the long run it had not revived, but rather ended, the resistance against the occupation of Czechoslovakia.

${ }^{30}$ Josef Beran, Jan Palach, quoted after Josef Sadecký (ed.), Živé pochodně (Zürich, 1980), 64 .

${ }^{31}$ Holy, The Little Czech, 45.

${ }^{32}$ Kamiński, 'Przeciw totalnej tyranii zła', 49. 
In 1979, for instance, the writer Ludvík Vaculík, founder of the Samizdat publishing house Edice petlice and a signatory of Charta 77, wrote an essay entitled Poznámky o statečnosti (Remarks on Courage). ${ }^{33}$ In the essay, he strongly criticized some of his co-Chartists for making themselves martyrs by being too courageous and provocative. His arguments sparked off a debate about reasonable possibilities for acting according to one's convictions and questioned the strategy of some dissidents of provoking their own imprisonment by different forms of public activity. One of the main opponents to Vaculík in this debate was Václav Havel. In his autobiographical novel Český snár̆, which was published one year later, Vaculík summarized his point of view as follows:

What does it help if on the one side a little group of tireless fighters shines, while on the other side a whole society devolves into total dissolution ... Unattainable examples make the depression of the others worse. Someone has to give millions of people absolution because they did not burn themselves like Jan Palach, because they did not strike, because they went to the election, because they did not sign the Charta 77 , and because they may not be able to withstand various violent measures. ${ }^{34}$

From Vaculík's point of view, the danger of any heroization - be it Palach or one of his co-dissidents - lay in its demobilizing effect. In fact, such doubts about the long-term effects of spectacular acts of resistance are nothing new in the discourse on Palach. Individual voices that criticized Palach's heroization as a national martyr could already be discerned in the days between his act, death, and funeral. Among those critics were members of Hnutí revoluční mládeže (The Movement of Revolutionary Youth): The group around Petr Uhl rejected the pure, passive mourning and discussed radical options to continue Palach's protest instead. ${ }^{35}$

Obviously, it is the distinction between passivity and activity i.e., between being a victim and a hero - that is problematic for any

${ }^{33}$ Ludvík Vaculík, 'Poznámky o statečnosti', in $Z$ dějin českého myšlení o literatuře. Antologie k dějinám české literatury, iv (Praha, 2005), 238-40.

${ }^{34}$ Idem, Český snár (Praha, 1980), 25.

${ }^{35}$ One idea discussed after the funeral was - as the group's member, Jaroslav Suk, later recalled - to blow up a Soviet tank as "Torch No. 2". Ota Filip et al. (eds.), Počátky odporu proti normalizačnímu režimu ve vzpomínkách účastníků. Materiály, studie, dokumenty (Praha, 1997), 23. 
mobilizing political usage. The question of the general usefulness of Palach's or Siwiec's 'self-sacrifice' is related to the difficulty of drawing these distinctions. As the political situation in Czechoslovakia did not change for the better, one can consider both acts of self-immolation to be pointless. A positive consideration is therefore only possible by means of a moral interpretation, as Łukasz Kamiński writes: "The aim of Siwiec was not a protest in and of itself ... but to reach the conscience of Poles and not only them." 36 By bearing in mind these acts of protest as appeals to the individual's conscience, they gain the status of heroic acts on an ethical level. Passing on this moral appeal to contemporary society seems to be the desire of today's historical writing and commemorative projects. The question of whether there is a lack of morally motivated interest or a simple lack of knowledge about a pre-existing interest is seen differently, as evident in one of Kamiński's articles in IPN's monthly journal, Pamieć.pl. In it, the president of IPN summarized the significance of Siwiec in the following way:

Ryszard Siwiec did not achieve his intended goal. Protests against the intervention died out, both in Poland and in other countries. But this does not mean, however, that his sacrifice was in vain. His heroism evokes admiration even today, as evidenced by the unflagging interest in the life and death of this extraordinary person. ${ }^{37}$

IV

A SACRIFICE FOR WHOM? CZECHOSLOVAK REFORM COMMUNISM AND POLAND'S ROLE IN THE MILITARY INTERVENTION OF 1968

The second set of obstacles in appropriation refers not to the ambivalent form of Siwiec's and Palach's acts but to their political content: the Prague Spring and the military intervention in Czechoslovakia. By looking closer at the commemorative texts, it turns out that the

${ }^{36}$ Kamiński, 'Przeciw totalnej tyranii zła', 50.

${ }^{37}$ Ibidem. In the online version of the journal article, the last sentence provides a link to the advertising website of the multimedia project Krzyk szarego człowieka <http://pamiec.pl/pa/biblioteka-cyfrowa/publikacje/12814,quotKrzykszarego-czlowieka-Ryszard-Siwiec-19091968quot-E-book-przeznaczony-na-u.html> [Accessed: Oct. 15, 2015]. 
events of 1968 continue to serve as a problematic reference point for both Czechs and Poles. On the one hand, Palach's commitment to Czechoslovakian reform socialism seems to be part of a rather unbeloved moment of Czech history. The student's enthusiasm for Dubček and his co-reformers in the Communist Party (Komunistická strana Československa, KSČ) needs to be harmonized with today's master narrative of Palach as a fighter against the Communists. On the other hand, Siwiec's protest touches on another 'embarrassing' part of this story - the participation of Polish units in the intervention into the ČSSR. From this point of view, both heroes are blemished by the fact that, on closer examination, they did not give their lives simply for their own nations, but rather for collective issues and concerns that do not form part of today's national narrative - namely, the reform Communist experiment and demonstrations of solidarity with the Czechoslovakian people. So, how could these difficult elements be integrated into the Palach commemoration? And what does the fact of Siwiec's motivation imply for the politics of memory surrounding him?

If we look at the commemorative press articles which recall Jan Palach's significance as a national hero year after year since 1990, we find a very homogenous narrative. The newspapers usually write about his motivation by providing the simplified explanation that he had "protested against the Soviet occupation". Without variation, his funeral is labelled "a national manifestation of freedom and democracy". The rigid usage of these phrases points to the gap between the annually ritualized commemoration and the obstacles to addressing the Prague Spring movement directly. Thus, until around 2005, we hardly find any explanation of the historical and political context of 1968/9.38 The description of Palach's "struggle for freedom and democracy" becomes a fairly empty phrase. The young student's commitments to reform socialism and his support for Alexander Dubček and other politicians of 1968 have all been erased from public discourse. In the course of the 1990s, the depoliticization of his motivation was merged into the totalitarian paradigm that rejected the period of state socialism en bloc and left no space for differentiation.

While this revaluation of the Prague Spring as a non-specific "struggle for freedom" helped to domesticate the appropriation

38 These findings are based on my analysis of the main Czech daily newspapers from 1990-2013. 
problems examined in Palach's case, Siwiec's role in the Czech-Polish relationship points in another direction. Like a huge part of Polish society, Siwiec had sympathized with the liberalization in Czechoslovakia. However, in protesting against the Warsaw Pact invasion he was in a small minority. The political situation in the summer of 1968 was tense and full of fear: The anti-Semitic campaign that had started in 1967 intensified political tensions, freedom of speech was increasingly curtailed, and in March 1968 student demonstrations in Warsaw, Gdańsk, Cracow, and other Polish cities were violently suppressed. A lot of potential protesters had already been arrested in spring. ${ }^{39}$ According to Jerzy Eisler, the attitude of the majority was characterized by apathy and indifference. ${ }^{40}$ From this point of view, Siwiec's protest could not achieve its aim at all. As some of his contemporaries emphasized, his deed had missed the right historical moment. „He did that ten years to early”, ${ }^{41}$ claimed later the eye witness Grażyna Niezgoda.

The 'shame'42 of the Polish participation in the invasion of Czechoslovakia, reveals another potential symbolic significance of Siwiec: His protest could serve as a tool for Czech-Polish reconciliation. And indeed this might have been one of the main driving forces behind the rare commemorative initiatives since 1989. In June 1989, the Siwiec-Palach-Community addressed Czechoslovakian society in Tygodnik Solidarność. In their text, the authors asked for "Christian forgiveness for the shameful participation of Polish soldiers"43. The impulse behind the community's foundations was described in the same article as follows: ${ }^{44}$

1. To commemorate the mentioned heroes and properly honour them ...

2. To tell our societies the truth about the embarrassing 'white spots' in our common history.

${ }^{39}$ Petr Blažek, 'Polska żywa pochodnia', in Ryszard Siwiec. Pro Memoria, 43-55, here 47.

${ }^{40}$ Jerzy Eisler, Polski rok 1968 (Warszawa, 2006), 747-8.

${ }^{41}$ Grażyna Niezgoda in Dębska and Kaliski (eds.), Całopalny, 34.

42 "Hańba tego czynu mówi sama za siebie", Ryszard Siwiec: 'Posłanie', in ibidem, 30-2, here 32.

43 'Posłanie do Czechów i Słowaków w 21. rocznicę inwazji na CSRS wojsk Układu Warszawskiego', Tygodnik Solidarność, 11 (1989).

${ }^{44}$ See also the explanations by Zygmunt Karcz in Gazeta Wyborcza (7 Aug. 1989), quoted after Dębska and Kaliski (eds.), Całopalny, 37. 
3. To promote solidarity and greater rapprochement between our people, who are historically closely linked in the Slavic family. ${ }^{45}$

Those early agents of remembrance were interested in Siwiec not primarily as a Polish national or anti-Communist hero, but as a promoter of the bilateral relationship between Poles and Czechs. Contrary to this, from the very beginning, Palach served as an integrative national martyr. Thus, it becomes clear that in the comparison between Jan Palach and the 'Polish Palach'46 it is not only in terms of prominence that Siwiec is an unequal symbol. From the point of his (re)discovery in 1989/1990 onwards, Siwiec became a far more CzechPolish than a Polish symbol of resistance. Even today, when compared to the very few Polish initiatives to maintain Siwiec's memory, Czech actors participate in his remembrance at least to the same extent as Poles do. Besides, a lot of commemoration activities are organized in the form of Czech-Polish co-operation ${ }^{47}$ and many make their appearance as adapted versions of Jan Palach commemoration projects. ${ }^{48}$ It is also important to note that one of the first scholars to conduct research on Siwiec using archival materials was the Czech historian Petr Blažek. ${ }^{49}$ Since 2011, a small group of Czechs living in Warsaw has organized annual commemorations at the monument in Warsaw. ${ }^{50}$

Ryszard Siwiec's hybrid position, caught between two national discourses, seems to be one of the obstacles to framing him as a Polish hero. The Czech initiatives are appreciated in Poland, but a lot of them are not recognized. Sometimes, the minor position of Siwiec next to

45 'Posłanie do Czechów i Słowaków'.

46 Zawada, 'Należy mu się hołd pamięci', Biuletyn Informacyjny Obozu, 44 (5 March 1989), 7; Karcz, 'Polski Palach'; Peters, 'Nieznany Polski Palach'.

47 In 2008, the Polish Institute had organized a concert 'In memoriam Ryszard Siwiec' with the Czech philharmonic orchestra in Prague. The commemoration in 2009 was organized by the town of Dębica together with the Czech embassy and the Czech Centre Warsaw. In addition, a mutual Czech-Polish ceremony for Palach and Siwiec was held in 2012 in Mělník (Czech Republic).

${ }^{48}$ Commemorations around Palach have become very vivid since the anniversary of his death in 2009. As argued above, this can clearly be understood as one of the main impulses behind fostering the memory of Siwiec.

${ }^{49}$ At the same time, Blažek was the first to study Jan Palach's self-immolation on the basis of archival material.

${ }^{50}$ Dariusz Grzędziński 'Warszawa Czesi uczcili pamięć Ryszarda Siwca. Aleš Šostok: To nasz wspólny bohater’, Polska Times (13 Sept. 1915). 
the world famous Palach is even - quite paradoxically - understood as a lack of Czech appreciation that they have to correct. Thus, in his novel Śmierć czeskiego psa (Death of a Czech Dog), the Polish writer Janusz Rudnicki commented on the supposed Czech ignorance in drastic words: "the case shows that even when we burn ourselves for someone, we do it for fuck all." 51

\section{$\mathrm{V}$ \\ SUMMARY: WHO BY FIRE?}

When contrasting the discourses that have developed around Jan Palach and Ryszard Siwiec, a clear hierarchy of icons begins to emerge. Although Siwiec had set himself on fire four months prior to Jan Palach, the Czech student functions as a kind of 'proto-martyr', ${ }^{52}$ who introduced self-immolation into the repertoire of resistance in Communist East Central Europe. The reason for Siwiec's almost complete absence in the collective memory of Poles, Czechs, and other nations is usually explained by the suppression of all information about his act of protest in the People's Republic of Poland, which has had a lasting effect until today. I agree that this is a major factor. In addition to this, on the level of iconography, Palach's 'advantage' is striking: the 20-year-old student was an unknown entity when he suddenly burst into the discourse of the international media. His youth and beauty - photos show him as a dark-haired, sensitive boy - predestined his fate as a 'young martyr' ${ }^{53}$ In contrast to this, Siwiec, a 59-year-old father of five children, did not fit into any pre-structured world of symbols. He called himself an 'ordinary man', and it would appear that he was too ordinary for a national hero.

However, as I demonstrated in this paper, the reasons for Siwiec's marginal position can be also found in the inherent limits of heroization. I argued that Ryszard Siwiec's self-immolation escapes any codification as a national martyr for two reasons: the general ambivalence of notions tied to 'oppositional self-sacrifice' and his position as a 'Polish Palach' caught between Czech and Polish frames of references.

${ }^{51}$ Janusz Rudnicki, Śmierć czeskiego psa (Warszawa, 2009), 134.

52 Lorenz Graitl, Sterben als Spektakel. Zur kommunikativen Dimension des politisch motivierten Suizids (Wiesbaden, 2012), 144.

${ }^{53}$ Martin Putna, 'Archetyp mladého mučedníka', in Blažek et al. (eds.), Palach '69, 169-75. 
These findings provide a new perspective on the connection between history, memory, and politics - namely, on the Sisyphean futility of some historical-political campaigns.

The most recent initiative aimed at remembrance by IPN Rzeszów is an example of the dilemma caused by the tension between the will to commemorate and a lack of commemoration. Placed within the framework of resistance heroes in East Central Europe, Siwiec's act of protest is endowed with considerable importance. It is presented as a crucial moment of protest against the Communist regime that should be better known in Poland, the Czech Republic, and beyond. Siwiec, however, in spite of the ongoing project, is still far from becoming a national or international hero and has assumed a very ambivalent position in the post-socialist discourse of resistance. This gap is evident on various discursive levels. In 2009, some historians and publicists launched a media campaign to name the newly built National Stadium in Warsaw after Ryszard Siwiec. They failed. Instead, only a small inhospitable street next to Stadium received his name. ${ }^{54}$ Likewise, doubts seem to linger in the historiographical discourse about the significance of Siwiec: the encyclopaedia of oppositional actors in East Central Europe, published by the Polish KARTA archive in $2007,{ }^{55}$ placed a picture of Siwiec's self-immolation on the cover of the volume. The fact that no article in the book is devoted to the tragic figure of Ryszard Siwiec speaks for itself.

proofreading Christopher Gilley

\section{SELECTED BIBLIOGRAPHY}

Blažek Petr et al. (eds.), Palach '69 (Praha, 2009).

Blažek Petr, Ryszard Siwiec 1909-1968 (Praha, 2010).

Brenner Christiane, 'Tod für einen Sozialismus mit "menschlichem Gesicht". Jan Palach', in Rainer Gries et al. (eds.), Sozialistische Helden. Eine Kulturgeschichte von Propagandafiguren in Osteuropa und der DDR (Berlin, 2002), 256-66.

54 The question whether this very street is dignified enough to honour Siwiec in Warsaw - especially in respect of the more appropriate street in Prague - was discussed by the city council. Maciej Maciejowski, in Dębska and Kaliski (eds.), Całopalny, 47.

${ }^{55}$ Stownik dysydentów. Czołowe postacie ruchów opozycyjnych $w$ krajach komunistycznych $w$ latach 1956-1989, i (Warszawa, 2007). 
Culek Josef (ed.), Palach. 11.8.1948-19.1.1969 (Praha, 1990).

Dębska Agnieszka and Kaliski Bartosz (eds.), Catopalny. Protest Ryszarda Siwca (Warszawa, 2013).

Eisler Jerzy, Polski rok 1968 (Warszawa, 2006).

Filip Ota et al. (eds.), Počátky odporu proti normalizačnímu režimu ve vzpomínkách účastníkỉ. Materiály, studie, dokumenty (Praha, 1997).

Gambetta Diego (ed.), Making Sense of Suicide Missions (Oxford, 2005).

Graitl Lorenz, Sterben als Spektakel. Zur kommunikativen Dimension des politisch motivierten Suizids (Wiesbaden, 2012).

Holy Ladislav, The Little Czech and the Great Czech Nation. National identity and the post-communist social transformation (Cambridge MA, 1996).

Kaliski Bartosz (ed.), 'Płomień Ryszarda Siwca', Karta, 44 (2005), 78-97.

Kamiński Łukasz, 'Przeciw totalnej tyranii zła. Ryszard Siwiec (1909-1968)', Pamięć.pl, 9 (2013), 48-50.

Prečan Vilém et al. (eds.), Horký leden 1989 v Československu (Praha, 1990).

Pynsent Robert B., Questions of Identity - Czech and Slovak Ideas of Nationality and Personality (New York, 1994).

Sabatos Charles, 'Hořící tělo jako ikona odporu. Jan Palach v české a světové literatuře', Kuděj, vi, 2 (2004), 59-77.

Sadecký Josef (ed.), Živé pochodně (Zürich, 1980).

Sabine Stach - 20th century history; postdoctoral research fellow at the German Historical Institute in Warsaw; e-mail: stach@dhi.waw.pl 